\title{
DETERMINATION OF THE WATER CONTENT RETAINED IN ACRISOL AND LIXISOL USING PEDOTRANSFER FUNCTIONS
}

\author{
Determinação do conteúdo de água retido em Latossolo Amarelo Distrófico e \\ Argissolo Vermelho Eutrófico utilizando funções de pedotransferência
}

\author{
Petrus Luiz de Luna Pequeno ${ }^{1}$, Flávio Pereira de Oliveira ${ }^{2}$, Adriana Ferreira Martins ${ }^{3}$, \\ Raphael Moreira Beirigo ${ }^{4}$, Jairo André Schlindwein ${ }^{5}$ \\ Recebido em 30 de setembro de 2019; aceito em 03 de março de 2020; disponível on-line em 12 de maio de 2020
}

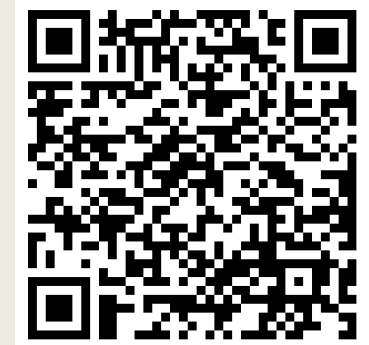

PALAVRAS CHAVE:

Solo e água;

Capacidade de campo;

FPT;

Variáveis Texturais;

Variáveis estruturais;

\section{KEYWORDS:}

Soil Data bank;

Aplication;

PTF;

Textural variables;

Structural variables.

* Contato com os autores:

${ }^{1}$ e-mail: petrusdeluna@unir.br (P. L. L. PEQUENO )

Professor/Pesquisador/Líder do Grupo de Pesquisa Aplicado a Modelos preditivos Ambientais - GPAMPA/Departamento Acadêmico

de Engenharia Civil/Núcleo de Tecnologia, Fundação Universidade Federal de Rondônia-

${ }^{2}$ e-mail: pereira@cca.ufpb.br ( F. P. OLIVEIRA )

Professor/Orientador do Programa de Pós-Graduação em Ciência do Solo - UFPB - Areia-PB

${ }^{3}$ e-mail: biol.adriana@gmail.com (A. F. MARTINS)

Professora/Pesquisadora da Universidade Federal da Paraíba - UFPB - AREIA-PB.

${ }^{4}$ e-mail: raphael@cca.ufpb.br (R. M. BEIRIGO)

Professor/Orientador do Programa de Pós-Graduação em Ciência do Solo - UFPB - Areia-PB

${ }^{5}$ e-mail: jairojas@unir.br (J. A. SCHLINDWEIN)

Doutor, Professor/Pesquisador, Fundação Universidade Federal de Rondônia 


\section{INTRODUCTION}

The water retention phenomenon by the soil in different matrix potentials is directly correlated with the mineralogical, textural and structural characteristics of the soil. The soil structural importance has already been highlighted by Hillel (1998), who states that in soil matrix potentials less negative (higher), capillary forces are more active, and the soil water retention is directly influenced by soil structure (aggregation, macro and microporosity).

In this sense, regarding the matrix component, for the capillarity phenomenon the soil structure and texture have a significant importance, where what negatively affect these two components, will a direct effect on capillarity, such as compaction, for example. Already the phenomenon of adsorption happens with the progressive emptying of the pores and only a film of water covers the solid particles, in this stage the energy of retention is much greater, where the air will occupy the space previously occupied by the water, and the matrictial component becomes more negative, that is, there is influence of the clay contents too, besides the microporosity.

Despite the destac importance of the structure and granulometry in soil water retention, their respective determinations are onerous, difficult to determine and not part of the routine of determinations of most soil analysis labs. From these limitations, mathematical models, also called pedofunctions or transfer functions were developed with the aim of to determine some of these attributes, of difficult to determine, from others attributes of easy determination. According to BARROS \& JON VAN LIER (2014), these denominations were replaced in the soil science by the term "pedotransference function" by BOUMA \& VAN LANEN (1986) and BOUMA (1989).

To McNeil et al. (2018), pedotransfer function is a statistical model obtained from field observations, along with the corresponding detailed laboratory measurements, describing the relationship between soil properties and the model developmented. According them, there are several methods that can be used to develop PTFs for the soil, according to an adopted property definition, and the choice of which method is used depends on the range of soil characteristics available, the restrictions that the modeler may want to apply to take into account the known functional behavior of water dynamics in the soil and the application or model in which PTFs are likely to be used.

In your review about pedotransfer functions (PTF) used to predict hydraulic conductivity of soil, ZHANG \& SCHAAP (2019) affirm that, in general, PTF aim to estimate difficult to obtain soil hydraulic, thermal characteristics, solute transport coefficients, or other soil properties, from easy-to-measure and /or widely available soil properties (e.g., soil texture and bulk density from soil survey).

ARRUDA et al. (1987), in Brazil, were one of the precursors in the generation of these predictives models analyzing the relationships between field capacity, permanent wilting point and soil density with texture, in soils called "highland" and agricultable. Then, SILVA et al. (1990) established the first FPTs for the semi-arid region using also deformed soil samples. Already, OLIVEIRA et al. (2002) used deformed and undisturbed soil samples on the development of FPT for soils of the state of Pernambuco, inferred that the relationship between water retention and soil texture narrows as tension increases.

DALBIANCO (2009) developed pedotransfer functions for the estimation of soil hydraulic conductivity in Rio Grande do Sul based on soil physical-water attributes. According to the authors, those functions whose predictive variables involved structural attributes showed good predictive capacity, while those with only textural attributes could not explain the variations.

According to MICHELON (2010), FPTs allow basic soil information, available in soil survey reports or in Geographic Information Systems, to 
be transformed into other, more difficult and generally costly of determination. The principle of FPTs consist is that the information system, or data, make it possible to express, in a mathematical way, pedotransfer functions specific to a variety of properties and soil qualities.

In the case of FPT generation methodologies, SOARES (2013) tested multiple linear regression and neural networks in the generation of pedotransfer functions using water retention data from the Rio Grande do Sul State soils, Brazil, grouped according to the textural class, independent of the type of sampling of soil that generated it, and concluded that the FPT origined from the neural networks presented better predictive capacity than those obtained across multiple linear regression.

Considering that structural influence on water retention in the soil occur in low matricial potentials, having the microporosity with principal responsible, and that with the elevation of these potentials, the textural parameters, in particular the clays, begin to act, is perceived then the importance of the type sampling of soil, since the joint analysis of the structural and textural attributes in the generation of pedotransfer functions can provide better precision in the retained water content estimates.

Another aspect portrayed in BARROS \& JON VAN LIER (2014) there is need to improve the quality of the database and the development of pedotransfer functions according to the regional edaphoclimatic conditions, in order to obtain results with less variation and greater reliability, which was corroborated by Souza et al. (2016) working with development and application of local PTF and PTF of the literature to soil bulk density ( $\rho b)$ estimation. Their conclused was that the estimates of $\rho b$ obtained with the PTFs compiled from the literature presented lower accuracy than those derived from the PTFs derived for their study.

However, accordind ZHANG et al. (2019), even though it is known that the performance of PTFs is influenced by the dataset used for calibration and evaluation and that a PTF may perform well in the region for which it was developed and been most sensitive to those properties that exhibit the largest variation in that region and at the particular scale, its application in other regions does not always yield satisfactory results, and therefore the reliability of a PTFs needs to be critically examined.

In this sense, the present research aimed to estimate the volumetric content of water retained in the soil using pedotransfer functions developed from a specific database created for the edaphoclimatic condictions of Agreste Paraibano region, Brazil.

\section{MATERIALS AND METHODS}

\subsection{Formation of the databank}

The databank utilized in the generation and validation of pedotransfer functions was created from the analytic results of 240 deformed and undisturbed soil samples collected on the 0-5 $\mathrm{cm}, 5-10 \mathrm{~cm}$ and $10-20 \mathrm{~cm}$ depths on the soil classes: Acrisol, Lixisol, Ferrasol, Leptosol, Arenosol and Planosol in Agreste Paraibano Region, both belonging to the representative soils bank of the Paraíba State of the Department of Soils and Rural Engineering/Federal University of Paraíba/Brazil. The analytical determinations regarding soil physical attributes were performed in the DSER / CCA / UFPB soil physics laboratory and included: granulometry, dispersed clay in water, flocculation degree, soil density, macroporosity, microporosity, total porosity, hydraulic conductivity of the saturated soil and the water retention curve in the matrix potentials $-0.006,-0.01,-0.033,-0.1,-0.3$, $0.5,-1.0$ and $-1.5 \mathrm{MPa}$, through the methodology of DONAGEMA et al. (2011). The particle density was obtained by the volumetric balloon method, according to FORSYTHE (1975). The stability of aggregates followed the methodology described by TISDALL et al. (1978), adapted by CARPENEDO 
\& MIELNICZUCK (1990) and the aggregate stability index determined by SILVA \& MIELNICZUK (1997). The organic carbon were determined through the methodology described in TEDESCO et al. (1995). The database was randomly divided, where $60 \%$ of the total sample was destined for generation and the other $40 \%$ for validation of the pedotransfer functions.

\subsection{Soil classes evaluated}

In the present research the soil classes studied were: a) Acrisol (PVd) located at geographic coordinates 6058'32.1"S and 3543'19.2" W (Areia-PB), whose regional relief is ondulated, with convex vertents or slightly concave, valleys in $\mathrm{V}$ and of flat bottom (Brazil, 1972), and mineralogy with of predominant kaolinite, clay mineral of group 1:1, with low area surface specific in relation to those of the group $2: 1$, but which confers to this class of soil a better aggregation (MONTEIRO, 2010) and; b) Lixisol (PVe), located at geographic coordinates 7001'55.4 "S and 35-38'48.8" W (Alagoa Grande-PB), with regional relief with $\mathrm{V}$-valleys and flat bottoms and some elevations in the form of an orange half, also occurring the relief strong ondulated (BRASIL, 1972). According to MONTEIRO (2010), the rock biotite-hornblende gneiss presents a more mafic mineralogy (rich in iron and magnesium). The content of $\mathrm{Al}_{2} \mathrm{O}_{3}$ found is compatible with the mineralogy of clay with predominance of kaolinite.

\subsection{Generation and Obtaining of the Pedotransfer functions (FPT)}

The datas were submitted to statistical analysis $(P \leq 0,05)$ using the SAS statistical software, where, firstly, was realized a simple correlation analysis between all variables aim to verify those predictors variables that were most related with the predicted variables. Afterward, multiple regression analysis was carried out using the "Stepwise" option, to obtaining the pedotransfer functions, where the levels of sand (very coarse, coarse, medium, fine, very fine and total sand), silt, clay, natural clay, flocculation degree, soil bulk density, particle density, aggregation index, organic matter, macro and microporosity was the independent variables of the equation. For generate the pedotransfer functions (PTF), utilized mean values of the three depths, were adopted as $0-20 \mathrm{~cm}$, aiming at greater representativeness and precision, and avoiding the generation of one PTF per depth.

\subsection{Evaluation of the efficiency of pedotransfer functions (PTF)}

The efficiency of the generated functions was analyzed graphically, following the methodology used by OLIVEIRA et al. (2002), BERNARDES (2010), MICHELON (2010), NASCIMENTO et al. (2010) by the relation 1:1 of the estimated data versus those observed and by the statistical indicators: $R^{2}$ - Coefficient of determination, with significance $P \leq 0.05$; $M E-$ Mean error (indicates the accuracy of the estimate, revealing the tendency of PTF to overestimate (if positive) or to underestimate (if negative) the determined values, being the closer to zero the ME, the greater the PTF accuracy); RMSE - root mean square error (indicates the dispersion of the measured and estimated values around the 1: 1 line, where the closer to zero the better the fit between data), according to Equations 01 and 02:

$$
\begin{gathered}
M E=\frac{1}{n} \sum_{i=1}^{n}(e i-m i) \\
R M S E=\sqrt{\frac{1}{N}} \sum_{i=1}^{N}(e i-m i)^{2}
\end{gathered}
$$

Where:

ME - Mean error

$\mathrm{n}=$ number of observations;

ei $=$ value estimated by the PTF of the variable of interest;

$\mathrm{mi}=$ measured value of the variable of interest (observed). 


\section{RESULTS AND DISCUSSION}

Table 1 presents the descriptive statistic referring of the sand, silt and clay contents determined in the PVd and PVe soil classes. The predominance of the sand and clay fractions, in that order, was verified in the three depths in both classes.

According to MONTEIRO (2010), in the first soil class is due to the fact that it is very weathered, originating from rocks of the PreCambrian such as biotite gneiss, which justifies the clay fraction content, besides the alterations of primary minerals such as feldspar and biotite constituents of biotite gneiss. In the second soil class, according to the author, the origin material is biotite hornblende gneiss (rock that presents a more mafic mineralogy, that is, rich in iron and magnesium) and the high levels of clay may be result of the local undulated relief and well drained.

This results, combined with the structural soil parameters can probably to indicate a good water retention on PVe, principally if we consider the clay contents in each soil class. The importance this graulometrics parameters on the water retention of soil is highlighted by Klein \& Klein (2015), since they are not modificate with the time, except if we to consider million years under by intemperism action.

Tables 02 and 03 present the Pearson ( $r$ ) linear correlation coefficients between granulometrics variables and structural with the moisture contents retained in differents matrix potential, used to generate and validate the pedotransfer functions (PTF). In the soil class PVd, the variable that best correlated positively with the moisture contents retained in all tensions was the microporosity, denoting that improvements in this variable can cause too an increase in the retained water contents. In soil bulk density was verified inverse behavior, where the highest negative values of the Pearson correlation index occurred, demonstrating that the lower the soil bulk density, the better the water retention. The granulometric fractions, except for clay, and the organic matter presented a low correlation with the retention of water. Of the soil granulometric components, the clay fraction was the only one to present a median correlation with the water retention in all the matrix potentials, being higher than the other fractions.

TABLE 1. Minimum, average and maximum values of sand, silt and clay contents in of $0-20 \mathrm{~cm}$ depth in the two soil

\begin{tabular}{|c|c|c|c|c|c|c|c|c|c|c|c|c|}
\hline \multirow{4}{*}{ Soil Classes } & \multicolumn{4}{|c|}{ Sand } & \multicolumn{4}{|c|}{ Silt } & \multicolumn{4}{|c|}{ Clay } \\
\hline & \multicolumn{12}{|c|}{ - } \\
\hline & Mi. & Md & $M x$ & DP & Mi. & Md & $\mathbf{M x}$ & DP & Mi. & Md & $\mathbf{M x}$ & DP \\
\hline & \multicolumn{12}{|c|}{$0-20 \mathrm{~cm}$} \\
\hline$P V d$ & 646 & 732 & 815 & 70 & 69 & 93 & 117 & 20 & 107 & 175 & 253 & 62 \\
\hline PVe & 490 & 544 & 618 & 53 & 98 & 124 & 165 & 30 & 247 & 333 & 404 & 67 \\
\hline
\end{tabular}

Where: Mi - Minimum value; Mx - Maximum value; Md - average value; DP - standard deviation of the mean; PVd - Acrisol; PVe - Lixisol.

SOURCE INFORMATION: The Author 
TABLE 2. Correlation coefficient $(r)$ between predictor variables and the moisture contents retained in different matrix potential in Acrisol (PVd) soil samples utilized to generate and validate the pedotransfer functions

\begin{tabular}{|c|c|c|c|c|c|c|c|c|}
\hline \multirow[b]{2}{*}{ Variables } & \multicolumn{8}{|c|}{ Matrix Potencial, MPa } \\
\hline & $\boldsymbol{\theta}_{-0,006}$ & $\boldsymbol{\theta}_{-0,01}$ & $\boldsymbol{\theta}_{-0,033}$ & $\theta_{-0,1}$ & $\boldsymbol{\theta}_{-0,3}$ & $\boldsymbol{\theta}_{-0,5}$ & $\theta_{-1}$ & $\boldsymbol{\theta}_{-1,5}$ \\
\hline AMG & $-0,43$ & $-0,50$ & $-0,56$ & $-0,55$ & $-0,51$ & $-0,56$ & $-0,56$ & $-0,58$ \\
\hline AG & $-0,19$ & $-0,28$ & $-0,26$ & $-0,26$ & $-0,23$ & $-0,27$ & $-0,26$ & $-0,31$ \\
\hline AME & 0,23 & 0,19 & 0,32 & 0,30 & 0,26 & 0,32 & 0,32 & 0,32 \\
\hline $\mathrm{AF}$ & $-0,16$ & $-0,09$ & $-0,07$ & $-0,07$ & $-0,13$ & $-0,01$ & $-0,02$ & 0,03 \\
\hline AMF & $-0,52$ & $-0,39$ & $-0,44$ & $-0,44$ & $-0,48$ & $-0,37$ & $-0,38$ & $-0,33$ \\
\hline SAND T & $-0,35$ & $-0,41$ & $-0,36$ & $-0,36$ & $-0,38$ & $-0,33$ & $-0,33$ & $-0,35$ \\
\hline SILT & $-0,47$ & $-0,37$ & $-0,39$ & $-0,40$ & $-0,39$ & $-0,40$ & $-0,43$ & $-0,40$ \\
\hline CLAY & 0,57 & 0,60 & 0,55 & 0,55 & 0,57 & 0,52 & 0,53 & 0,55 \\
\hline $\mathrm{MO}$ & 0,01 & 0,04 & 0,06 & 0,06 & $-0,01$ & 0,11 & 0,12 & 0,16 \\
\hline DS & $-0,90$ & $-0,89$ & $-0,93$ & $-0,92$ & $-0,92$ & $-0,88$ & $-0,89$ & $-0,86$ \\
\hline MICP & 0,96 & 0,87 & 0,86 & 0,85 & 0,86 & 0,82 & 0,85 & 0,85 \\
\hline MACP & 0,05 & 0,18 & 0,27 & 0,26 & 0,25 & 0,27 & 0,22 & 0,19 \\
\hline IEA & $-0,09$ & $-0,11$ & $-0,25$ & $-0,23$ & $-0,22$ & $-0,19$ & $-0,16$ & $-0,11$ \\
\hline GFLOC & $-0,09$ & $-0,20$ & $-0,12$ & $-0,12$ & $-0,11$ & $-0,08$ & $-0,08$ & 0,01 \\
\hline ADA & 0,24 & 0,41 & 0,29 & 0,29 & 0,29 & 0,25 & 0,25 & 0,17 \\
\hline $\mathrm{DP}$ & $-0,67$ & $-0,48$ & $-0,54$ & $-0,51$ & $-0,51$ & $-0,42$ & $-0,44$ & $-0,41$ \\
\hline
\end{tabular}

Where: AMG: very coarse sand; AG: coarse sand; AME: medium sand; AF: fine sand; AMF: very fine sand; SAND T: total sand; OM; organic matter; SD: soil bulk density; MICP: microporosity; MACP: macroporosity; IEA: index of the stability of aggregates in water; GFLOC: degree of flocculation; ADA: clay dispersed in water; DP: particle density. SOURCE INFORMATION: The Author

In soil class PVe, the variable that best correlated was microporosity (MICP) in matrix potentials $\Psi_{-0.006}$ and $\Psi_{-0.01}$ with values of $r$ equal to 1.00 and 0.99, respectively. Soil bulk density correlated negatively with water retention in all potentials, thus demonstrating the deleterious influence of high values on the soil structure, consequently on water retention. From the granulometric components, the clay fraction presented the best value of $r$ in $\Psi_{-0.033}$ with more lower values, but higher than the other granulometric fractions, in the other matrix potentials.

In the same tables (2 and 3), the negative correlations between different matrix potential and sand contents (total and subdivision) denote likely a low influence this granulometric fractions on the water content retented by soils. The soil microporosity (MICP), demonstrated a high correlation with all matrix potentials, denoting his importance, together the soil texture, on the soil capacity of the water retention, don't occurred with the macroporosity (MACP), which has its influence on the percolation of water in the soil profile. Costa et al. (2013), found in their research similar results and said that soils with greater fine sand contents also have greater contents of medium sand and very fine sand, and lower contents of organic matter, and these properties were responsible for the reduction in Field Capacity in soils with higher fine sand contents. According this authors, the porosity total of soil (macro and microporosity) it is correlated with matrix potentials low (0.006 to $0.033 \mathrm{MPa}$ ) and high (1.5 MPa). 
TABLE 3. Correlation coefficient ( $r$ ) between predictor variables and the moisture contents retained in different matrix potential in Lixisol (PVe) soil samples utilized to generate and validate the pedotransfer functions (PTF).

\begin{tabular}{l|c|c|c|c|c|c|c|c}
\hline \multirow{2}{*}{ Variables } & \multicolumn{7}{|c}{ Matrix Potencial, $\mathbf{M P a}$} \\
\cline { 2 - 10 } & $\boldsymbol{\theta}_{-\mathbf{0}, 006}$ & $\boldsymbol{\theta}_{-0,01}$ & $\boldsymbol{\theta}_{-0,033}$ & $\boldsymbol{\theta}_{-0,1}$ & $\boldsymbol{\theta}_{-0,3}$ & $\boldsymbol{\theta}_{-0,5}$ & $\boldsymbol{\theta}_{-1}$ & $\boldsymbol{\theta}_{-1,5}$ \\
\hline AMG & $-0,06$ & $-0,06$ & 0,00 & $-0,01$ & $-0,01$ & 0,03 & $-0,01$ & $-0,05$ \\
\hline AG & $-0,20$ & $-0,19$ & $-0,60$ & $-0,48$ & $-0,41$ & $-0,38$ & $-0,35$ & $-0,30$ \\
\hline AME & 0,01 & 0,02 & $-0,48$ & $-0,29$ & $-0,21$ & $-0,20$ & $-0,17$ & $-0,15$ \\
\hline AMF & 0,02 & 0,02 & $-0,45$ & $-0,25$ & $-0,18$ & $-0,15$ & $-0,11$ & $-0,07$ \\
\hline SAND T & $-0,02$ & 0,00 & $-0,38$ & $-0,16$ & $-0,07$ & $-0,03$ & 0,04 & 0,18 \\
\hline SILT & $-0,02$ & $-0,01$ & $-0,48$ & $-0,29$ & $-0,21$ & $-0,18$ & $-0,14$ & $-0,10$ \\
\hline CLAY & $-0,34$ & $-0,32$ & $-0,13$ & $-0,17$ & $-0,15$ & $-0,14$ & $-0,09$ & 0,01 \\
\hline MO & 0,18 & 0,16 & 0,53 & 0,36 & 0,28 & 0,24 & 0,18 & 0,09 \\
\hline DS & $\mathbf{0 , 5 1}$ & $\mathbf{0 , 5 1}$ & 0,17 & 0,38 & 0,42 & $\mathbf{0 , 3 9}$ & $\mathbf{0 , 3 9}$ & $\mathbf{0 , 4 2}$ \\
\hline MICP & $-0,76$ & $-0,75$ & $-0,57$ & $-0,75$ & $-0,74$ & $-0,72$ & $-0,70$ & $-0,70$ \\
\hline MACP & $\mathbf{1 , 0 0}$ & $\mathbf{0 , 9 9}$ & $\mathbf{0 , 4 1}$ & $\mathbf{0 , 6 3}$ & $\mathbf{0 , 6 7}$ & $\mathbf{0 , 6 5}$ & $\mathbf{0 , 5 8}$ & $\mathbf{0 , 5 4}$ \\
\hline IEA & $-0,21$ & $-0,20$ & $-0,19$ & 0,15 & 0,21 & 0,21 & 0,29 & 0,34 \\
\hline GFLOC & 0,18 & 0,14 & 0,27 & 0,13 & 0,11 & 0,06 & 0,00 & $-0,04$ \\
\hline ADA & 0,09 & 0,07 & 0,27 & 0,11 & 0,09 & $-0,01$ & $-0,06$ & $-0,07$ \\
\hline DP & 0,09 & 0,11 & $-0,12$ & 0,06 & 0,04 & 0,17 & 0,19 & 0,16 \\
\hline Whe & 0,09 & 0,11 & $-0,54$ & $-0,03$ & 0,14 & 0,12 & 0,16 & 0,16
\end{tabular}

Where: AMG: very coarse sand; AG: coarse sand; AME: medium sand; AF: fine sand; AMF: very fine sand; SAND T: total sand; MO; organic matter; DS: soil bulk density; MICP: microporosity; MACP: macroporosity; IEA: index of the stability of aggregates in water; GFLOC: degree of flocculation; ADA: clay dispersed in water; DP: particle density. SOURCE INFORMATION: The Author

\subsection{Pedotransfer functions for the soil class Acrisol (PVd)}

The table 4 shows the pedotransfer functions obtained to predict the water contents retained in the soil class Acrisol (PVd) at matrix potentials $-0.006,-0.01,-0.033,-0.1,-0.3,-0.5,-1.0$ and -1.5 MPa. Observed that in the matrix potential $\Psi_{-0.006}$ only structural components contributed to FPT generation (macro and microporosity), where microporosity was responsible for $91 \%$ of the retention water variation. In the other potentials, the contributions were through structural and granulometric components, with the soil bulk density being present in all except $\Psi_{-0.006}$, with contribution varying from 74 to $86 \%$ in the variation of the water content retained. From the granulometric components, the variations occurred from 7 to $10 \%$, where the clay variable been present in the potentials $\Psi_{-0.001}$ and $\Psi_{-0.3}$ and AG (coarse sand) in the potentials $\Psi_{-0.033}, \Psi_{-0.1}, \Psi_{-0.5}, \Psi_{-1.0}, \Psi_{-1.5 \text {. }}$

Figure 1 shows the predictive capacity of each PTF evaluated using the 1:1 relation (data present in the database obtained through the Richards extractor and data estimated by the FPT) associated to the statistical indicators $\mathrm{R}^{2}, \mathrm{ME}$ and RMSE for the soil class PVd. It is observed on the Figure 1 $\left(\Psi_{-0,006}\right)$ that comparison between the values observed and those estimated through FPT, together with the values of ME and RMSE, show that there was a slight underestimation of the retained water values ( $\left.M E=-0,0002 \mathrm{~cm}^{3} \mathrm{~cm}^{-3}\right)$. It is Comparing the trend lines and the relation $1: 1$, it was observed that there was a small underestimate of the water content retained in the soil from values greater than $0.130 \mathrm{~cm}^{3} \mathrm{~cm}^{-3}$. The dispersion of values around the 1:1 relation was small, according to RMSE $\left(0.006 \mathrm{~cm}^{3} \mathrm{~cm}^{-3}\right)$, resulting in the high determination coefficient $\mathrm{R}^{2}=0.96$. 
TABLE 04. Pedotransfer functions in different matrix potentials for estimate of the water retention on the soil class Acrisol (PVd) on the Areia microregion, Paraíba State in the 0-20 cm depth.

\begin{tabular}{|c|c|c|c|c|c|}
\hline \multicolumn{3}{|c|}{$\Psi_{-0,006}\left(R^{2}=0,95\right)$} & \multicolumn{3}{|c|}{$\Psi_{-0,01}\left(R^{2}=0,88\right)$} \\
\hline Variables & Coefficient & Partial $\mathbf{R}^{\mathbf{2}}$ & Variables & Coefficient & Partial $\mathbf{R}^{2}$ \\
\hline Intersec. & $-0,08937$ & & Intersec. & 0,35488 & \\
\hline MICP & 0,84861 & 0,91 & clay & 0,00014083 & 0,09 \\
\hline MACP & 0,24272 & 0,04 & DS & $-0,17004$ & 0,78 \\
\hline \multicolumn{3}{|c|}{$\Psi_{-0,033}\left(R^{2}=0,94\right)$} & \multicolumn{3}{|c|}{$\Psi_{-0,1}\left(R^{2}=0,92\right)$} \\
\hline Variables & Coefficient & Partial $\mathbf{R}^{\mathbf{2}}$ & Variables & Coefficient & Partial $\mathbf{R}^{\mathbf{2}}$ \\
\hline Intersec. & 0,24907 & & Intersec. & 0,24077 & \\
\hline AG & $-0,00007519$ & 0,07 & AG & $-0,00007373$ & 0,07 \\
\hline DS & $-0,11508$ & 0,86 & DS & $-0,11337$ & 0,85 \\
\hline \multicolumn{3}{|c|}{$\Psi_{-0,3}\left(R^{2}=0,91\right)$} & \multicolumn{3}{|c|}{$\Psi_{-0,5}\left(R^{2}=0,85\right)$} \\
\hline Variables & Coefficient & Partial $\mathbf{R}^{\mathbf{2}}$ & Variables & Coefficient & Partial $\mathbf{R}^{\mathbf{2}}$ \\
\hline Intersec. & 0,19530 & & Intersec. & 0,21718 & \\
\hline Clay & 0,00006975 & 0,07 & $A G$ & $-0,00007239$ & 0,07 \\
\hline DS & $-0,10280$ & 0,84 & DS & $-0,10248$ & 0,78 \\
\hline \multicolumn{3}{|c|}{$\Psi_{-1,0}\left(R^{2}=0,86\right)$} & \multicolumn{3}{|c|}{$\Psi_{-1,5}\left(R^{2}=0,84\right)$} \\
\hline Variables & Coefficient & Partial $\mathbf{R}^{\mathbf{2}}$ & Variables & Coefficient & Partial $\mathbf{R}^{2}$ \\
\hline Intersec. & 0,20934 & & Intersec. & 0,19817 & \\
\hline$A G$ & $-0,00006859$ & 0,07 & AG & $-0,00007741$ & 0,10 \\
\hline DS & $-0,09921$ & 0,79 & DS & $-0,09215$ & 0,74 \\
\hline
\end{tabular}

Where; AG - coarse sand; MICP - microporosity; MACP - macroporosity; DS - soil bulk density.

SOURCE INFORMATION: The Author

At the figure $1\left(\Psi_{-0.01}\right)$ where FTP has as independent variables clay and DS, it's observed a tendency to underestimate the soil water retained content in relation to observed $\left(\mathrm{ME}=-0,0009 \mathrm{~cm}^{3}\right.$ $\mathrm{cm}^{-3}$ ). As a matrix potential influenced by soil structure (Hillel, 1998), demonstrated in the correlation analysis, according to table 4, whose $r^{2}$ of the microporosity (MIC) was equal to 0.87 , it was expected MICP with the one of the variables present in the FPT, but it did not occur, since the Stepwise procedure selects the best model from the inclusion or exclusion of predictor variables, and this variable not had fit within this method. A dispersion of the values with respect to the straight line 1: 1 was observed, demonstrated by the RMSE value of $0.008 \mathrm{~cm}^{3} \mathrm{~cm}-3$ generating a $R^{2}$ equal to 0.87 , denoting a good fit of the model.
In Figures $1\left(\Psi_{-0.033}\right), 1\left(\Psi_{-0,1}\right), 1\left(\Psi_{-0,5}\right)$, $1\left(\Psi_{-1,0}\right)$, and $1\left(\Psi_{-1,5}\right)$, when observed the values of ME, RMSE and $R^{2}$ in both potentials, it was verified that there was a slight underestimation of the retained water contents in relation to those observed, a small dispersion of the data around the 1: 1 line corroborated by the high values of the coefficients of determination. These results allow to infer that these FPTs presented satisfactory accuracy in the estimation of water retention in the respective potentials for the Acrisol soil class (PVd). In Figure $1\left(\Psi_{-0.3}\right)$, the set of statistical indicators show that the slight overestimation of the data in relation to those observed did not interfere in the good accuracy of the model. 

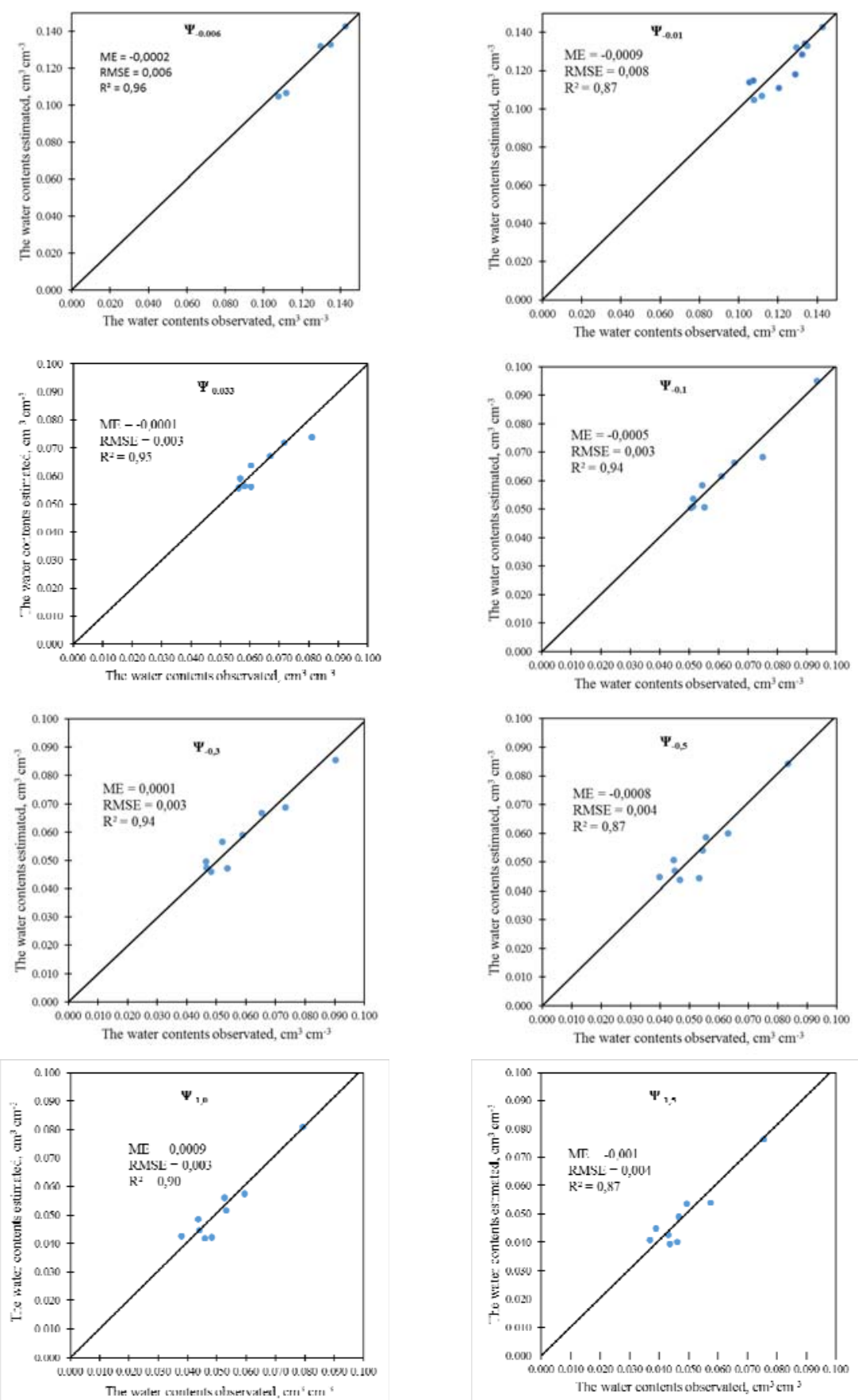

FIGURE 1. Comparison between estimated and observed values of the water content retained in potentials $\Psi_{-0.006}, \Psi_{-}$ $0.01, \Psi_{-0.033}, \Psi_{-0.1}, \Psi_{-0.3}, \Psi_{-0.5}, \Psi_{-1.0}$ and $\Psi_{-1.5} \mathrm{MPa}$ in the soil class Acrisol (PVd) on the Areia microregion, Paraíba State, Brazil.

SOURCE INFORMATION: The Author

OLIVEIRA et al. (2002), also used datas of granulometric and soil bulk density to generate pedotransfer functions for Pernambuco soils, including Ferrasol and Acrisol soil classes, and checked that only in the $\Psi_{-1,5}$ potential the correlation between observed and estimated data presented lower variation with $R^{2}=0.92$ and low for $\Psi_{-0.033}$. When they comparing with of other FPT of the literature, with the same composition of independent variables, they also verified low predictive capacity.

FIDALSKI \& TORMENA (2007) developed pedotransfer functions in Acrisol under management systems with cover crops permanent 
in citrus and obtained PTF dependent on soil bulk density, organic carbon and water retention curves adjustment. In the present study, the soil bulk density dependence occurred in all matrix potentials except $\Psi_{-0.006}$, where soil porosity was the one that provided the best result in the stepwise model.

NASCIMENTO et al. (2010) developed pedotransfer functions for the matrix potentials $\psi$ -0.033 and $\Psi_{-1.5}$, using database containing information of the soil granulometric, soil density and organic carbon values referring to soil classes Ferrasol and Acrisol, formed by NASCIMENTO (2005) from the literature. According to the authors, most of the estimates underestimated or overestimated the values of retained water contents, where for prediction of $A D$ (available water) the model presented low predictive capacity. Considering as AD the contents retained between the potentials $\Psi_{-0.033}$ and $\Psi_{-1.5}$, the pedotransfer functions generated by the present research showed an efficient predictive capacity, even though only DS, clay and AG were independent variables.

\subsection{Pedotransfer functions for the soil class Lixisol (PVe)}

The pedotransfer functions generated and presented in table 05 in the different matrix potentials show that in the highest potentials $\left(\Psi_{-0.006}\right.$ and $\left.\Psi_{-0.01}\right)$ the influence of soil structure, through soil porosity, that was most significantly contributed to the PTF composition, being responsible for 99 and $98 \%$, respectively, of the variation of the water content retained. Result congruent with those presented in Table 3, where a high positive correlation was observed between microporosity and water retention in these potentials.
In the $\Psi_{-0.033}$ PTF was composed of three variables (AG, DS and DP) that presented a high negative correlation with water retention, where reductions of these imply an increase in water

retention. Thus, the $72 \%$ variation of retained water contents was the responsibility of these variables.

From the potential $\Psi_{-0.033}$ the soil bulk density (DS) was the component common to all others potentials and with greater contribution of the quantitative variation of water retained. With negative correlation varying from 0.70 to 0.75 (Table 3 ), the presence of this variable as the main component in the PFT indicated that the water retentions will depend on the reduction in your values, since the variation in the retained quantitative occurs due to this (48 to $56 \%$ ).

Considering that the influence of the granulometric variables on the water retention in the soil occurs with the reduction of the matrix potential (becoming more negative), it was also observed that in this class of soil only the variable Coarse Sand (AG) it obtained significance for selection by the Stepwise process but restricted only to potentials $\Psi_{-0.033}$ and $\Psi_{-0.1}$.

The data estimated by the PTFs presents in table 05 were compared with the observed data and also analyzed by statistical indicators in the different matrix potentials and their results shown in figure 2 . In the higher potentials (figures $2\left(\Psi_{-0.06}\right)$ and $2\left(\Psi_{-0.01}\right)$, the underestimation and overestimation of the data occurred were very small, demonstrated by the respective ME values. The dispersions around the 1: 1 line were also very low, providing a $R^{2}$ equal to 0.99 in both, denoting an almost perfect fit. The set of statistical indicators also showed that PTFs presented a good accuracy and can be used to predict the water content retained in these potentials. 
TABLE 05. Pedotransfer functions in different matrix potentials for estimate of the water retention on the soil class Lixisol (PVe) on the Areia microregion, Paraíba State in the 0-20 cm depth.

\begin{tabular}{|c|c|c|c|c|c|}
\hline \multicolumn{3}{|c|}{$\Psi_{-0,006}\left(R^{2}=0,99\right)$} & \multicolumn{3}{|c|}{$\Psi_{-0,01}\left(R^{2}=0,99\right)$} \\
\hline Variables & Coefficient & Partial $\mathbf{R}^{2}$ & Variables & Coefficient & Partial $\mathbf{R}^{2}$ \\
\hline Intersec. & $-0,04922$ & & Intersec. & $-0,03442$ & \\
\hline DS & 0,03254 & 0,006 & DS & 0,03132 & 0,008 \\
\hline MICP & 0,68355 & 0,99 & MICP & 0,59511 & 0,98 \\
\hline \multicolumn{3}{|c|}{$\Psi_{-0,033}\left(R^{2}=0,72\right)$} & \multicolumn{3}{|c|}{$\Psi_{-0,1}\left(R^{2}=0,67\right)$} \\
\hline Variables & Coefficient & Partial $\mathbf{R}^{\mathbf{2}}$ & Variables & Coefficient & Partial $\mathbf{R}^{\mathbf{2}}$ \\
\hline Intersec. & 0,33983 & & Intersec. & 0,19797 & \\
\hline$A G$ & $-0,00037477$ & 0,36 & $A G$ & $-0,00032586$ & 0,11 \\
\hline DS & $-0,06527$ & 0,21 & DS & $-0,07464$ & 0,56 \\
\hline DP & $-0,05612$ & 0,14 & & & \\
\hline \multicolumn{3}{|c|}{$\Psi_{-0,3}\left(R^{2}=0,54\right)$} & \multicolumn{3}{|c|}{$\Psi_{-0,5}\left(R^{2}=0,52\right)$} \\
\hline Variables & Coefficient & Partial $\mathbf{R}^{2}$ & Variables & Coefficient & Partial $\mathbf{R}^{2}$ \\
\hline Intersec. & 0,18361 & & Intersec. & 0,18811 & \\
\hline DS & $-0,07838$ & 0,54 & DS & $-0,08465$ & 0,52 \\
\hline \multicolumn{3}{|c|}{$\Psi_{-1,0}\left(R^{2}=0,48\right)$} & \multicolumn{3}{|c|}{$\Psi_{-1,5}\left(R^{2}=0,48\right)$} \\
\hline Variables & Coefficient & Partial $\mathbf{R}^{\mathbf{2}}$ & Variables & Coefficient & Partial $\mathbf{R}^{\mathbf{2}}$ \\
\hline Intersec. & 0,18168 & & Intersec. & 0,16288 & \\
\hline DS & $-0,08206$ & 0,48 & DS & $-0,07336$ & 0,48 \\
\hline
\end{tabular}

Where: DS - soil bulk density; MICP - microporosity; AG - Coarse Sand; DP - particle density SOURCE INFORMATION: The Author

Underestimations was verifycated too in the predicted datas by the PTFs for the matrix potentials $-0.033,-0.3$ and $-0.5 \mathrm{MPa}$ (Figures $2\left(\Psi_{-0.033}\right), 2 \quad\left(\Psi_{-0.3}\right)$ and $\left.2\left(\Psi_{-0.5}\right)\right)$, whose ME values were $-0.001,-0.0007$ and $-0.00008 \mathrm{~cm}^{3} \mathrm{~cm}^{-3}$, respectively. Only in the first one the dispersion around the 1: 1 line (RMSE $=0.004 \mathrm{~cm}^{3} \mathrm{~cm}^{-3}$ ) contributed to a smaller adjustment between the data and, consequently, to a regular accuracy of the PTF in the prediction of the water content retained in those matrix potential.

It is also observed in the figures $2\left(\Psi_{-0,1}\right)$, $2\left(\Psi_{-1,0}\right)$ and $2\left(\Psi_{-1,5}\right)$ that the respective FPTs tended to overestimate the data ( $\mathrm{ME}$ equal to $0.0005,0.0001$ and $0.0001 \mathrm{~cm}^{3} \mathrm{~cm}^{-3}$, respectively), but not affecting theirs accuracy. The PTFs presented a low dispersion between values observed and predicted around the 1:1 line, according to RMSE and $\mathrm{R}^{2}$ values.
MICHELON (2010), working with PTFs in soils of Rio Grande do Sul, utilized structural and granulometric variables in FPTs generated in the potentials $-0.033 ;-0.1 ;-0.5$ and $-1.5 \mathrm{MPa}$. The former were responsible for most of the variation of the water content retained in the first two potentials, while in the lower potentials (- 0.5 and $1.5 \mathrm{MPa}$ ) were the granulometric variables.

The values of $r^{2}, M E$ and RMSE in the potential $-1,5 \mathrm{MPa}$ are better than those found by OLIVEIRA et al. (2002), using FPT in soils of the state of Pernambuco, with a database formed by deformed soil samples (ME $=0.0252 \mathrm{~cm}^{3} \mathrm{~cm}^{-3}$, RMSE $=0.0174 \mathrm{~cm}^{3} \mathrm{~cm}^{-3}$ and; $\left.r^{2}=0.92\right)$ and NASCIMENTO et al. (2010) when they developed PTF to estimate retention of water in Lixisol and Acrisol using a database of more than 1200 profiles of these soils in Coastal Tablelands $\left(\mathrm{ME}=0.0256 \mathrm{~cm}^{3} \mathrm{~cm}^{-3} ;\right.$ RMSE $=0.05 \mathrm{~cm}^{3} \mathrm{~cm}^{-3}$ and $\left.r^{2}=0.77\right)$. 

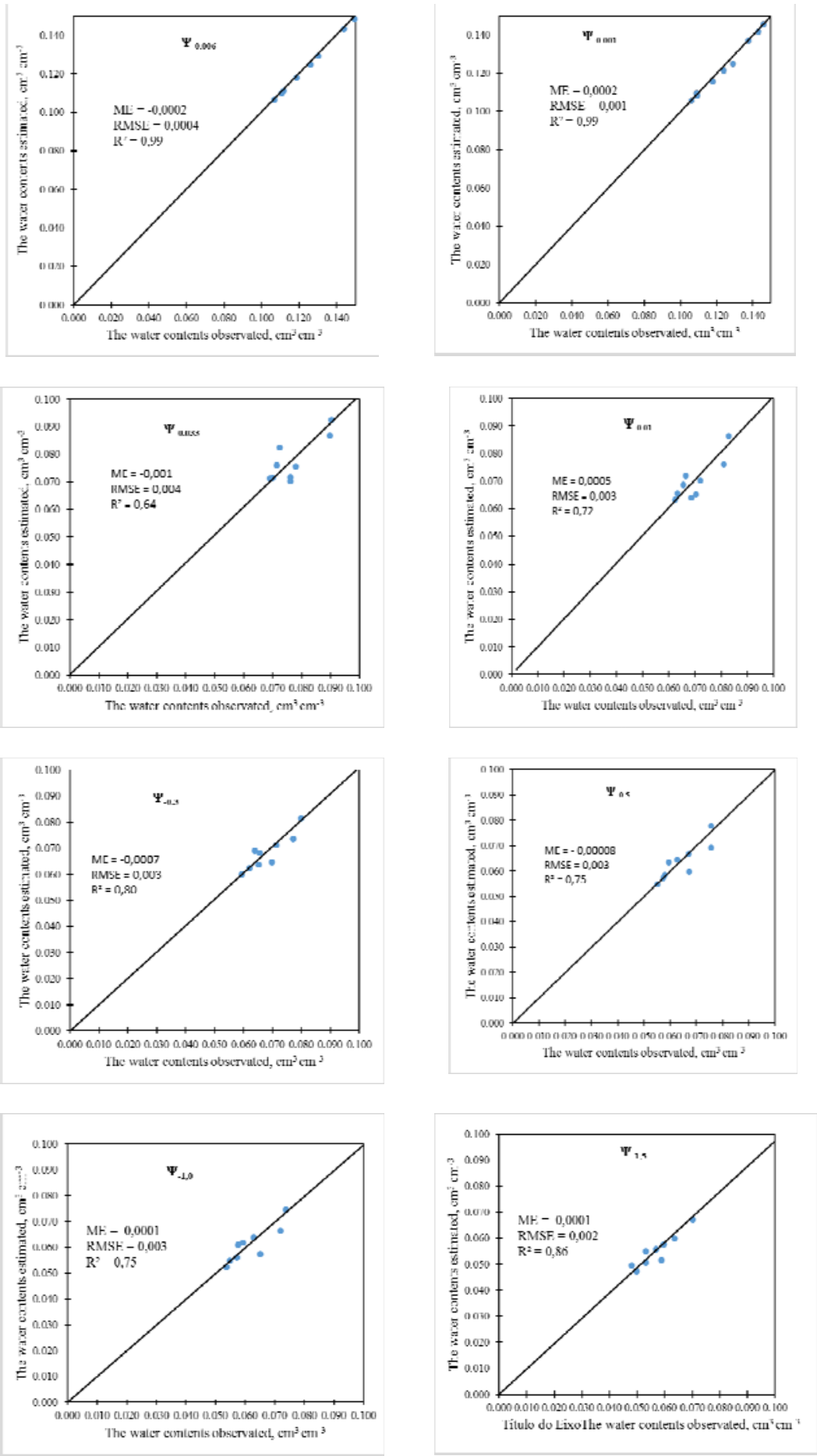

FIGURE 2. Comparison between estimated and observed values of the water content retained in potentials $\Psi_{-0.006}, \Psi_{\text {- }}$ $0.01, \Psi_{-0.033}, \Psi_{-0.1}, \Psi_{-0.3}, \Psi_{-0.5}, \Psi_{-1.0}$ and $\Psi_{-1.5} \mathrm{MPa}$ in the soil class Lixisol (PVe) on the Alagoa Grande microregion, Paraíba State. 


\section{CONCLUSION}

For the conditions of development of the research, can be concluded that:

- The qualification of the sampling type allowed to observe the occurrence of correlation between structural variables and water retention in the soil, reflected in the accuracy of the PTFs generated and validated for the soil classes PVd and PVe;

- The predominance of the sand fraction in the two classes of soils may have contributed to the reduction of soil microporosity and, consequently, its non-participation as an independent variable in FPT;

- The PTFs generated for the two soil classes showed low variation around the 1: 1 line and good accuracy and can be used to estimate the water content retained in these two classes of soils for the edaphoclimatic conditions of the Agreste Paraibano Region.

\section{REFERENCES}

ARRUDA, F. B.; ZULLO JUNIOR, J.; OLIVEIRA, J. B. Parâmetros de solo para o cálculo da água disponível com base na textura do solo. Revista Brasileira de Ciência do Solo, v. 11, p. 11-15, 1987.

BARROS, A. H. C.; JONG van LIER, Q. Pedotransfer for Brazilian soils. IN: TEIXEIRA, W. G. et al. Application of soil physics in environmental Analysis: measuring, modelling and data integration. Progress in soil science. Switzerland: Springer International Publishing. DOI 10.1007/978-3-319-06013-26. p. 131-162, 2014.

BERNARDES, R. S. Funções de pedotransferência e qualidade física de três solos do norte fluminense para a cultura do coqueiro anão. 2010. 140p. (Tese de Doutorado).Rio de Janeiro: UENF, 2010.

BRASIL. Ministério da Agricultura. Escritório de Pesquisa e Experimentação. Equipe de Pedologia e Fertilidade do Solo. I. Levantamento exploratório de Reconhecimento dos Solos do Estado da Paraíba. II. Interpretação para uso agrícola dos solos do Estado da Paraíba. Rio de Janeiro: 1972. 683 p. (Boletim Técnico, 15; SUDENE. Série Pedologia, 8)

BOUMA, J. Using soil survey data for quantitative land evaluation. Soil Science Society of America Proceedings, Madison, v. 9, p. 177-213, 1989.
BOUMA, J.; LANEN, H. A. J. Transfer functions and threshold values: from soil characteristics to land qualities. In: Beek, K., P. A. Barrough and D. D McCormack (Editors). Proc. WORKSHOP BY ISSS/SSSA ON QUANTIFIED LAND EVALUATION PROCEDURES, ITC publication.6., Enschede. Proceedings. Netherlands, 1986. p.106-111.

CARPENEDO, V.; MIELNICZUK, J. Estado de agregação e qualidade de agregados de Latossolos roxos, submetidos a diferentes sistemas de manejo. Revista Brasileira de Ciência do Solo, Campinas, v. 14, n. 1, p. 99-105, jan./abr. 1990.

COSTA, A.; ALBUQUerQUe, J. A.; ALMEIDA, J. A.; Costa, A.; LUCIANO, R. V. (2013). Pedotransfer functions to estimate retention and availability of water in soils of the state of Santa Catarina, Brazil. Revista Brasileira de Ciência do Solo, 37(4), 889-910. https://doi.org/10.1590/S0100-06832013000400007

DALBIANCO, L. Variabilidade espacial e estimativa da condutividade hidráulica e caracterização físico-hídrica de uma microbacia hidrográfica rural. 2009. 116 p. (Dissertação de Mestrado) Santa Maria: Universidade Federal de Santa Maria, 2009.

DONAGEMA, G. K., CAMPOS, D. V. B.; CALDERANO, S. B.; TEIXEIRA, W. G.; VIANA, J. H. M. (org.). Manual de métodos de análise de solos. 2 ed. Rev. Rio de Janeiro: Embrapa Solos, 2011. 230p. (Embrapa Solos, Documentos, 132).

FIDALSKI, J. \& TORMENA, C.A. Funções de pedotransferência para as curvas de retenção de água e de resistência do solo à penetração em sistemas de manejo com plantas de cobertura permanente em citros. Revista Ciência Rural, 37:1316-1322, 2007.

FORSYTHE, W. M. Física de suelos: manual de laboratório. San José: Instituto Interamericano de Ciências Agrícolas, 212 p., 1975.

HILLEL, D. Enviromental soil physics. Massachusetts: Academic, 1998. 771p.

KLEIN, C.; KLEIN, V. A. Estratégias para potencializar a retenção e a disponibilidade de água no solo. Santa Maria: Revista Eletrônica em Gestão, Educação e Tecnologia Ambiental, v. 19, p.21-29, 2015.

MCNEILL, S. J.; LILBURNE, L. R.; CARRICK, A.; WEBB, T. $\mathrm{H}$.; Pedotransfer functions for the soil water characteristics of New Zealand soils using S-map information. Geoderma, n. 326 (2018), p. 96-110.

MICHELON, C. J. Pedofunções para retenção de água de solos do Rio Grande do Sul irrigados por aspersão. 2010, 111p. (Tese de Doutorado). Santa Maria: Universidade Federal de Santa Maria, 2010. 
MONTEIRO, A. L. Caracterização mineralógica de solos representativos do estado da Paraíba. 139 p. 2010 (Dissertação de Mestrado). Areia: Universidade Federal da Paraíba, 2010.

NASCIMENTO, G. B.; ANJOS, L. H. C.; PEREIRA, M. G.; FONTANA, A.; SANTOS, H. G. Funções de pedotransferência do conteúdo de água em Latossolos Amarelos e Argissolos Amarelos. Revista Ciências Agrárias, v.5, n.4, p.560-569, out.-dez., 2010.

NASCIMENTO, G.B. Atributos diferenciais de Latossolos e Argissolos Amarelos: uma contribuição para o SiBCS. 2005. 143p. (Tese de Doutorado).Seropédica: Universidade Federal Rural do Rio de Janeiro, 2005.

OLIVEIRA, L.B.; RIBEIRO, M.R.; JACOMINE, P.K.T.; RODRIGUES, J.J.V.;Marques, F.A. Funções de pedotransferência para predição da umidade retida a potenciais específicos em solos do Estado de Pernambuco. Revista Brasileira de Ciência do Solo, v.26, n.2, p.315-323, 2002.

SILVA, A. S.; BRITO, L. T. L.; OLIVEIRA, C. A. V.; MOITA, A. W. Parâmetros de solo em função da umidade na capacidade de campo em áreas irrigáveis do trópico semiárido brasileiro. Brasília: Pesquisa Agropecuária Brasileira, v. 25, n.1, p. 103-116, jan. 1990.

SILVA, I. F.; MIELNICZUK, J. Avaliação do estado de agregação do solo afetado pelo uso agrícola. Revista Brasileira de Ciência do Solo, Campinas, v. 21, n. 2, p. 313-319, abr./jun. 1997.

SOARES, F. C. Uso de diferentes metodologias na geração de funções de pedotransferência para a retenção de água em solos do Rio Grande do Sul. 2013. 200 p. (Tese de Doutorado). Santa Maria: Universidade Federal de Santa Maria, 2013.

SOUZA, E.; FERNANDES FILHO, E. I.; SCHAEFER, C. E. G. R.; BATJES, N. H.; SANTOS, G. R.; PONTES, L. M.(2016). Funções de pedotransferência para estimar a densidade aparente das propriedades do solo e covariáveis ambientais: bacia do Rio Doce. Scientia Agricola, 73 (6), 525-534. https://doi.org/10.1590/0103-9016-20150485 .

TEDESCO, M. J.; GIANELLO, C.; BISSANI, C. A.; BOHNEN, H.; VOLKWEISS, S. J. Análises de solo, planta e outros materiais. Porto Alegre: UFRGS. Boletim técnico n. 5. 1995, 2 ed. rev. amp. 174p.

TOMASELLA, J.; HODNETT, M. ROSSATO, L. Pedotransfer functions for the estimation of soil water retention in Brazilian soils. Soil Science Society of America Journal, Madison, v. 64, p. 327-338, 2000.
ZHANG, $X$; ZHU j.; WENDROTH, O.; MATOCHA, C.; EDWARDS, D. 2019. Effect of macroporosity on pedotransfer function estimates at the field scale. Vadose Zone J. 18:180-151. doi:10.2136/vzj2018.08.0151. In: https://dl.sciencesocieties.org/publications/vzi/articles/ 18/1/180151.

ZHANG, Y.; SCHAAP, M. G. Estimation of saturated hydraulic conductivity with pedotransfer functions: $A$ review. Journal of Hydrology. V. 575, 2019, p. 10111030. https://doi.org/10.1016/i.jhydrol.2019.05.058 